\title{
COMMUNICATION AND MASS MEDIA IN DELILLO'S WHITE NOISE AND PYNCHON'S THE CRYING OF LOT 49
}

\author{
Ana Belén Pérez García, Universidad Nacional \\ de Educación a Distancia (UNED) \\ E-mail: ana_belen_perez_garcia@hotmail.com
}

\begin{abstract}
White Noise and The Crying of Lot 49 are considered Image Fiction novels, works that try to make visible the influence that mass media had on modern era. This is exemplified in both novels, as media deeply affect their plot's development as well as the characters' evolution and ways of communicating. This essay focuses on this from three main points of view: the extent to which the audience engages with the media in both works, the extent to which media become the only source of information and the consequences this may have, and the importance of concepts such as "noise," language or drugs in both novels.
\end{abstract}

Keywords: Mass media, communication, noise, miscommunication, involvement.

Resumen: White Noise y The Crying of Lot 49 se clasifican como "Novelas de imagen y ficción," obras que tratan de hacer visible la influencia que los medios de comunicación tuvieron en la era moderna. Éstos están presentes en ambas novelas, ya que los medios afectan el desarrollo de los argumentos, la evolución de los personajes y las formas de comunicación. Este ensayo se centra en esto desde tres puntos de vista: el grado en el que la audiencia se involucra con los medios de comunicación, el grado en el que los medios se convierten en la única fuente de información y las consecuencias que esto puede tener, y la importancia de conceptos como "ruido," lenguaje o drogas en relación con ambas novelas. Palabras clave: Medios de comunicación, comunicación, ruido, no-comunicación, involucramiento.

Literature and technology have gone hand in hand for ages. The invention of the printing press involved a whole revolution in the act and art of writing, and modern literature was born when reading became a massive but private business. Image Fiction novels are works that try to make visible the influence that television and mass media had on modern era, using thematic and ideological resources. ${ }^{1}$ White Noise by Don Delillo and The Crying of

1 It is the literature of a generation that was born and bred in a televisual culture, and who lived amidst selfconsciousness even before the term "metafiction" was coined. They learned that some "real" events would not occur if it were not for the presence of TV cameras, such as Vietnam protests, Greenpeace activism or even the Pope's trips. Thomas Pynchon's The Crying of Lot 49 (1966) and Jerzy Kosinsky's Being There (1971) can be considered two of the pioneers of American image-fiction novels, together with DeLillo's Americana (1971) and above all White Noise, the most representative work of this "genre.” Dàvid F. Wallace's Infinite Jest (1996) and 
Lot 49 by Thomas Pynchon can be considered Image Fiction novels as both show some of the characteristics of this type of literature and were published at a postmodern era that witnessed the development and importance that television and media in general were acquiring. They became the most important sources of communication and information, as ninety-nine per cent of American families had a television set in their houses by 1960 . The importance that television had could not be ignored or considered an external element to fiction, but as a part of the culture and life of the postmodern society, an integral part with far reaching and serious implications: "The formal storytelling function, once the property of literature, has been taken over by film and TV, which have also appropriated 19th century fiction's realistic mode....TV is virtually modern life" (Coyle et al. 1991: 137). This is clearly exemplified in Delillo's and Pynchon's works.

Television and radio appear as extremely relevant elements in White Noise and The Crying of Lot 49 as they deeply affected the novels' development as well as the characters' evolution and ways of communicating with other protagonists and with themselves. Indeed, the first thing that calls the attention of the reader while going through both works is the continuous presence of the media in most scenes, either as the central issue or as an external element which is not directly connected to the scene content but which is related to it somehow. In the former the tube is a constant point of reference for characters. Throughout the novel, television and radio appear continuously as background noise that although it does not affect communication directly, interrupts it and makes it difficult sometimes. In the latter, there are continuous allusions to elements such as God, drugs and television and they are always connected in some way, to communication. Volker Hummel referred to this saying:

Throughout White Noise the tube chatters along and makes cryptic announcements. Indeed, it is so much part of the household that it can be considered a member of the family. Like other broadcasting-devices, it seems to have life of its own (2007: 13).

Paying attention to this, the main aim of this essay is to demonstrate the way media affect the novels' development and the protagonists' ways of communicating attending to three main points of view: the extent to which the audience engages with the media in both works, the extent to which media become the only source of information and the consequences this may have for the characters and the plot, and the importance of concepts such as "noise" or language or drugs in both novels in relation to communication and media.

The extent to which the audience engages with the media can be measured in three main types, present in both novels: primary, secondary and tertiary involvement. In the first one the audience is solely concentrating on consuming the media text. An example of this can be found in The Crying of Lot 49 and the scene in which Oedipa meets Professor John Nefastis. When she arrives at the laboratory, he is watching kids programs and does not seem to be much interested in the woman. Indeed, although she is trying to put Maxwell's Demon into function, and although the process seems to be complicate and important, he prefers to continue watching the program rather than paying attention to what Oedipa was doing: "He returned to his TV set, which was now showing cartoons. Oedipa sat through two Yogi Bears, one Magilla Gorilla and a Peter Portamus, staring at Clerk Maxwell's

Bret E. Ellis’ American Psycho (1991) are of particular interest too. 
enigmatic profile, waiting for the Demon to communicate" (Pynchon 1966: 73). This attention to television is preventing communication between the two protagonists of the scene since the doctor does not explain anything about the functioning of the machine and does not seem to be very interested in communicating with Oedipa. In the case of White Noise, a clear example is that of the traditional Friday night watching television together. The family is together and watching television is their principal activity, although they do not communicate between each other, except to comment on events that appear on it.

Secondary involvement refers to the moment in which the audience's concentration is split between the media and another distraction, as in the case of the hotel scene. Here we see television is a source of confusion and one-sided communication. Oedipa watches television before Metzger showed up and the tube continues switched on although their meeting was really important for both of them. Indeed, as they are talking about business, they also watch a film and comment on it. Metzger tells her of his weird personal history, relating stories of his job as a child actor, and as he does so, they drink a large amount of tequila that Metzger has brought with him. This turns their attention from important matters to superficial ones.

Tertiary attention means that the media text is merely in the background, with no real concentration upon it at all, as for instance in White Noise where the radio seems to be a constant background noise in the protagonists' lives. The radio constantly switches on and off itself when Babette and Jack are talking about serious matters: "We spoke in drowsy whispers for a while: the radio came on...Later, after she'd fallen off my body and into a restless sleep, I kept on storing in the dark. The radio came on" (Delillo 1986: 189-93). Television also appears in The Crying of Lot 49 at the final scene in chapter two when the protagonists are having sex: "Her climax and Metzger's, when it came, coincided with every light in the place, including the TV tube, suddenly going out, dead, black. It was a curious experience" (Pynchon 1966: 27).

In both novels the television plays the role of another character, always ready to pipe up with useless commentary and observations at both intense and mundane moments: after dinner, during sex, during common conversations and in important conversations. Television seems to never rest and this, obviously has a consequence on communication. Because characters many times pay more attention to the media than to their interlocutors, communication is largely affected.

Another important point in the study of mass media and communication is that in the two novels we see that television is no longer an external element, but it becomes part of the characters' culture and the only way through which they receive information. Even more, sometimes, for them it is the most credible source of information, the issue through which they learn new things and through which they can teach others new things. Marshal McLuhan referred to this saying: "The news automatically becomes the real world for the TV user and is not a substitute for reality, but is itself an immediate reality" (1964: 272). Gerbner et al. also referred to the importance that television acquired as a cultural element: "Transcending historic barriers of literacy and mobility, television has become the primary source of everyday culture of an otherwise heterogeneous population" (cf. Tichi 1989: 111). That is, media is nowadays considered a window for learning and is also considered 
to be our main window to the world, playing a crucial role in forming and reflecting public opinion: the media connect the world to individuals and reproduce the self-image of society.

In these novels, the idea of media as the main and most credible source of information is presented in different scenes. In White Noise, Jack sees the effects of media upon his children. When he is speaking with Heinrich about the weather report, the boy says: "It's going to rain tonight" and Jack says "It is raining now" and Heinrich answers "The radio said tonight" to what later on Jack says " Just because it's on the radio doesn't mean we have to suspend belief in the evidence of our senses" (Delillo 1986: 22-23). Jack is bewildered at the effect of the radio on his son's perception of what is actually going on. He feels as if his children are growing up in a world filled with the media and it influences them so that they only trust what information is gained from television or radio. It means that experience is no longer immediate but mediated. For Heinrich, the actual truth is insignificant unless it is directly from a direct source of the radio or television, tools that are supposed to be the ultimate form of truth. This affects his way of communicating with his father, as he is unable to trust Jack's words or even his own senses. He rather prefers to believe what the media say, although this implies distrusting what his own eyes can see. Indeed, while most conversations between father and son are usually trivial, they debate the objectivity of reality, contents that lead their conversations nowhere. As Mark Miller said:

... the controlled commercial monopoly of the television has destroyed critical consciousness in the United States. We are "boxed-in" and must deconstruct the television text in order to disclose its technological "degradation of experiences," its debasement of "public culture", its exacerbation of racial, class, and gender based animosities (1988: 112).

Similarly, the traditional Friday night watching television for the Gladneys is an example of this, in this case, for opposite reasons. Unlike many families who watch television together without having much conscience about it, Babette "had made it a rule" (Delillo 1986: 16). According to Jack, Babette thinks that if children watch television with their relatives, they will consider this act less important and will rest relevance to what it is said on it, that is, the effects that television have on people and in this case on the children, would be reduced:

She seemed to think that if kids watched television one night a week with parents or stepparents, the effect would be to de-glamorize the medium in their eyes, make it wholesome domestic sport. Its narcotic undertow and eerie diseased brain-sucking power would be gradually reduced (Delillo 1986: 16).

In spite of Babette's efforts, children continue trusting what television says and being influenced by it in the same way. Indeed, her intentions finally have a negative consequence because instead of provoking the response she expected, both the children and Jack consider the night a nightmare and the children continue to be influenced by it: "The evening in fact was a subtle form of punishment for us all" (Delillo 1986: 16).

In The Crying of Lot 49, we also find examples of how characters learn things from television and are unable to detach from reality and media messages. Metzger and Oedipa's first conversation at the hotel was continuously interrupted by their comments about the 
movie they were watching. However, many of Inverarity's companies appeared on television during the commercials and as they were advertised, Metzger comments on them, showing Oedipa the difficult job they had ahead of them. Oedipa is learning from television the complexity of her ex-boyfriend's state. However, she is also shocked by the magnitude of the business and does not seem to doubt about the possible exaggerations that TV adverts usually make use of when advertising things or even that each commercial is an example of Pierce's holding of commercialism. She just accepts unconditionally all that is said in the media. This scene is an example of television surrounding us and trying to send us messages that for whatever reason, the characters do not understand. Indeed, one of the characteristics of postmodern literature is that characters lack psychological depth, meaning they do not care much about the meaning of things or situations surrounding them, but accept without wondering: "I didn't know," Oedipa smiled. On came a loud commercial for Fangoso Lagoons, a new housing development west of here. "One of Inverarity's interests" Metzger noted" (Pynchon 1966:19) and later on they say:

Into the commercial break now roared a deafening ad for Beaconsfield Cigarettes, whose attractiveness lay in their filter's use of bone charcoal, the very best kind.

"Bones of what?" wondered Oedipa.

"Inverarity knew. He owned fifty-one per cent of the filter process" (Pynchon 1966: 21).

According to Tichi "Commercial television continuously offers "truth"; public officials and spokesmen for consumer products proffer endless versions of "the real thing" (1989: 126) and they attract viewers as Oedipa is attracted by what she sees and learns about Inverarity's possessions without wondering what is behind these adverts and what type of consequences they would have in her own life. Guided by the images that television shows us, the viewers learn how to consume, they become desperate to live the same standards of acceptability that adverts show, so that they need to possess the goods and services that are advertised, no matter where they come from and whether they actually need them or not.

It is equally important to mention the extent to which people trust what television shows. This reaches its highest point as there are scenes in which characters consider that what is not televised or shown in the media is not real or valuable. Marshall Mcluhan referred to the importance provided to media:

The medium is the message because it is the medium that shapes and controls the scale and form of human association and action. The content or uses of such media are as diverse as they are ineffectual in shaping the form of human association (1964: 9).

There are some scenes in White Noise and The Crying of Lot 49 that reflect Mcluhan's idea of the media as a force of primary importance. In Delillo's novel we find an exemplifying scene, that of Bee's accident. An improvised narrator explains in detail all the problems they had during the landing. When Bee appears, instead of explaining her father about the accident or expressing her feelings and fears about it, the girl's only worry is to appear on the news and says: 
"Where is the media?" she said

"There is no media in Iron City."

“They went through all that for nothing” (Delillo1986: 92).

Suffering is for these characters only worthy if people know about it through the media. The same is exemplified during the airborne toxic event ${ }^{2}$. People are already safe at the refugee's camp and they are angry because nothing is said about the disaster on the network. Instead of being happy because they are safe, they worry why the rest of the world does not know about their problems, why their problems are not worth to be on television:

This is the most terrifying time of our lives. Everything we love and have worked for is under serious threat. But we look around and see no response from the official organs of the media... Even if there hasn't been great loss of life, don't we deserve some attention for our suffering, our human worry, our terror? Isn't fear news?" (Delillo 1986: 155).

Hummel makes reference to this saying:

The driving force behind the anger at the absent media is the notion that only their presence makes the suffering "real". If there are no cameras, then it is as if nothing really happened. "Televised" and "important event" have become synonymous for these characters (2007: 23).

Similarly the scene in which Oedipa and Hilarius are in the clinic is a good example of it. There is a moment in which a policeman asks Oedipa to keep Hilarius in a good position because the television people wanted to take some images of him. In the middle of such a tragic and dangerous event, instead of worrying about its possible consequences, the cop worries about the media having good images of it: "Can you talk him out of it? The cop wanted to know. TV folks would like to get some footage through the window. Could you keep him occupied?” (Pynchon 1966: 94).

On the other hand, television and radio present characters to worlds which are different from their own, making them be detached from the reality and watch things as movies in which they are not involved at all, because things happen to other people. This is also reflected in both novels and deeply affects the characters' behavior as well as their way of responding to these situations, and consequently of expressing themselves in such moments.

The airborne toxic event in White Noise and Jack's reaction to the catastrophe is an example of how characters are detached from reality due to television. Jack is so distanced from the real world in which media has become such a big part that even after the airborne event in his own town, he feels as if he is immune to such tragic disasters. Jack feels as if he is distanced from tragic events and although he has never experienced something similar, on television such events are portrayed as a kind of "movie", a representation of something that although it is really happening, is not really there:

2 In the novel, characters listen that a train car is derailed and burning chemical in the air, Nyodene Derivative or Nyodene D, a toxic substance that causes lumps in rats and that may cause nausea, skin irritation, sweaty palms and other symptoms. 
"These things happen to poor people who live in exposed areas. Society is set up in such a way that it's the poor and the uneducated who suffer the main impact of natural and man-made disasters... Did you ever see a college professor rowing on a boat down his own street in one of those TV floods." (Delillo 1986: 112).

Hummel (2007:17) refers to this:

The passage reveals of TV's most important functions for the viewer: it provides access to sealedoff areas where disasters do occur: far away, to poor people. That is why the Gladney family is so transfixed on their Friday night viewing ritual of TV catastrophes.

Although many of the characters seem to be provided with a false sense of reality from the media, yet the media seem to be the only real truth provision of information in the novels. Even instances such as massacres and crimes provide excitement and fascinate them because just by watching they can witness a tragedy from a distance. This happens as Oedipa is watching the tragic film in which Metzger was an actor. She expected the film to have a happy ending, as most movies have. However, the film has a tragic end that does not seem to cause any effect on the woman. She also sees her own life as being part of a movie due to the influence that media had on her: "... she had noticed the absence of intensity, as if watching a movie, just perceptibly out of focus that the projectionist refused to fix" (Pynchon 1966: 12). That is, television suggests that spectators can be put in touch with real life and at the same time it implies immunity from many of the effects of that reality. What is more, this impression of immunity is reinforced by the fact the viewer knows there is not a single flow but several channels of flow, which means that it reiterates constantly the idea that the world can be consumed and that those things appearing on television do not necessarily have to affect them. This may also happen to all of us, as we tend to see tragedies as something external to us because they are explained like a tale or a story in which others are protagonists.

An important example of the opposite, that is, of how television distances characters from reality is the only scene in which reality and media are mixed up and this is the moment in which Babette appears on television. It is a shocking moment for the family who at first feel unable to recognize the mother's presence in the tube. Because they are not used to see something familiar on television, it is hard and difficult for them to make a meaning of what they are watching. Jack said: "strangeness gripped me, a sense of psychic disorientation. It was her all right, the face, the hair, the way she blinks in rapid twos and threes. ... but her appearance on the screen made me think of her as some distant figure from the past ... It was but wasn't her" (Delillo 1986: 103). Now that someone close to him is on the media, he is unable to separate himself from it, but at the same time, he is also unable to feel any familiarity towards it. The only person in the family who still recognizes Babette is the baby, as he is not still aware of the influence of media, he is only watching his mother and cries for her: "Only Wilder remained calm. He watched his mother; spoke to her in half-words" (Delillo 1986: 103). This is also an example of Baudrillard's theory about Simulacra and simulations which is so relevant in Image Fiction literature. This scene is the first moment in which a family member appears on television and understandably they have a hard time recognizing her at first. Jack only sees her as the collection of pixels 
and light from the television and feels unable to separate the reality of the televised thing. Baudrillard explains it saying:

It is not longer a question of imitation, nor of reduplication, nor even of parody. It is rather a question of substituting signs of the real for the real itself: that is, an operation to deter every real process by its operational double, a metastable, programmatic, perfect descriptive machine which provides all the signs of the real and short-circuits all its vicissitudes (1998:1).

It is a clear example of how media affect common people, in a society which is governed by what we see on television. One of the examples is how people react to situations in which they are involved with the media themselves.

The basic assumption in human communication is that the message conveys a meaning, even when there is no meaning, we are to decode. Media is supposed to transmit information and help viewers communicate. However, the effects that media have in communication are not always positive as we see in The Crying of Lot 49 and White Noise. There are some examples of misinformation, that is, the more information, the less knowledge. In White Noise, initially the radio serves as the most important media the Gladneys rely on for information, describing the event and the symptoms it might cause. The symptoms keep being updated, but the two girls develop whatever symptom they hear about. Jack is unsure of the influence of the media to his children. He cannot tell if the media is causing them to actually imagine that they possess symptoms, because without its influence, his young daughters would not be aware of such side effects. Therefore, the more he learns in the radio from the effects of the toxic event, the less he understands and knows about the effects they have on his family. This fits Jean Baudrillard's idea about simulation:

Thus, feigning or dissimulating leaves the reality principle intact: the difference is always clear, it is only masked: whereas simulation threatens the difference between "true" and "false" and "imaginary". Since the simulator produces "true" symptoms, is he or she ill or not? (1998:1).

This is an example of how media control reality, even to the extent that we ignore our own senses: the girls consistently feel the symptoms of Nyodene D exposure only after the radio informs them of what they are, in the same way that Heinrich distrusts his own senses and is unable to trust other's words and even his own senses.

Similarly Jack mentions the word "misinformation" as he listens to his family's meaningless conversation about Dylar (Delillo 1986: 80-81):

"What do you know about Dylar?"

"Is that the black girl who's staying with the Sotvers?"

“That's Dakar," Steffie said.

"Dakar isn't her name, it's where she's from," Denise said. "It's a country on the ivory coast of Africa".

"The capital is Lagos," Babette said. "I know that because of a surfer movie I saw once where they travel all over the world". 
"The Perfect Wave", Heinrich said. "I saw it on TV".

"But what's the girl's name?" Steffie said.

"I don't know," Babette said, "but the movie wasn't called The Perfect Wave. The perfect wave is what they were looking for". ...

“It doesn't matter," Babette said, “because you can’t copyright titles anyway".

"If she's an African," Steffie said, "I wonder if she ever rode a camel."

"Try an Audi Turbo."

"Try a Toyota Supra."

"What is it camels store in their humps?" Babette said. "Food or water? I could never get that straight." ...

"Are you telling me a two-hump camel stores food in one hump and water in the other?"

"The important thing about camels," he said, "is that camel meat is considered a delicacy."

"I thought that was alligator meat", Denise said.

"Who introduced the camel to America?" Babette said. "They had them out west for a while to carry supplies to coolies who were building the great railroads that met at Ogden, Utah. I remember my history exams."

“Are you sure you're not talking about llamas?” Heinrich said.

“The llama stayed in Peru," Denise said. "Peru has the llama, the vicuña and one other animal. Bolivia has tin. Chile has copper and iron."

After listening to the conversation Jack says: "The family is the cradle of the world's misinformation. There must be something in family life that generates factual error. Over closeness, the noise and heat of being..." (Delillo 1986: 81). That is, the family is unable to maintain a conversation because they misunderstand the information that television and adverts provides them. This makes each of them trust only what they have watched on the media, even if they have not understood it or if the information does not fit in the conversation they are maintaining with other people. The family creates its own sort of white noise, falling into their own world of ill-formed facts. This is what Jack considers "misinformation".

Similarly, we find examples of "misinformation" and empty communication or failures in communication because of the influence of mass media in The Crying of Lot 49. Indeed the novel seems, in general, a reflection of the failures of the communication process. The messages are differed, changed or lost between the sender and its receiver and by the inability of the latter to decode it. Dan Geddes refers to this in his essay "Distorted Communication in Pynchon's The Crying of Lot 49" (2002: 2): 
Conversations, such as between Oedipa and her lawyer Roseman, are weirdly disconnected. Because his main themes are the unknowability of the universe and the limitations of communication, Pynchon need not supply the reader his any definite answers. He only poses difficult questions. ... Yet by the end, Pynchon provides no answers, only a comically dark portrait of his time (and perhaps Man's condition).

The same happens between Jack and his son. Because they speak about transcendental matters without paying attention to the reality and validity of their comments, their conversations do not reach any aim or objective, they are senseless and only based on what they have watched on television or heard somewhere in the media.

Similarly, Oedipa wonders from the first time she meets Metzger if she has been set up and if she is on the set of a performance. Her fears are validated when we learn Metzger was an actor but he is now a lawyer. In the same way, Manny di Presso arises as the lawyer turned actor turned lawyer. Oedipa's lawyer, Roseman, is continuously writing script to combat Perry Mason, a TV show character. That is, many of the characters to whom Oedipa has looked to for truth, information, validation or advice find themselves unable to separate their reality from the surrealism of television. This is, therefore, another symbol of empty communication, also exemplified in this novel when paying attention to letters. As television does not always provide information, but sometimes it is merely a source of entertainment, letters do not always imply a transmission of information. Many times, like in The Crying of Lot 49, they say nothing, they are meaningless. The novel contains a mail-delivery group that requires its members to mail a letter once a week even if they have nothing to say: "It is the principle," Fallopian agreed, sounding defensive. "To keep it up to some kind of a reasonable volume, each member has to send at least one letter a week through Yoyodyne system. If you don't, you get fined" (Pynchon 1966: 35). Apart from this, there are also letters which are not direct form of stable communication, as those between Oedipa and her husband. They do not tell anything. Similarly, although not directly related to television, there is another example of miscommunication in the novel, and this is The Courier's Tragedy, since a failure in communication is what drives much of the play's action.

Regarding the idea of failure of communication, we may also make reference to the importance of "noise" in both novels. The term is quite significant in White Noise, as it appears on the title. Heinz Ickstadt (1988: 107) refers to this:

White Noise is a term taken from radio technology. It refers to a permanent cosmic sound that we cannot hear because we are constantly exposed to it. In addition, "noise", in information theory, denotes super-abundance of information which makes meaningful communication impossible.

In the novel, this is clearly exemplified in many of the scenes we have mentioned above. There is a constant presence of the media in the novel, a constant background noise that prevents communication and interferes on it. The family's life seems to be a mixture of voices in which the radio or the televisions always seem to have something to say. As Ickstadt (1988: 107) says:

The family's inner space of communication is an ensemble of polyphonous voices: the voices of the constantly arguing children, the reasoned discourse of the family debates, the switched- 
on-off again voice of the radio, the uninterrupted noise coming from the television screen...In this world of voices, images, goods and advertisements- there are always advertisements in the background like "The TV- said."

However, in The Crying of Lot 49, we find that the idea of noise, although not directly exemplified, appears in many occasions too. John P. Leland (1974: 52) refers to this in his essay "Pynchon's Linguistic Demon: The Crying of Lot 49":

In any message of communication the amount of information that is finally received from the sender is of importance to information theorists. However, if the message sent is ambiguous, overly redundant, or if "noise" occurs from within or outside of the system, the level of information exchanged drops.

He provides an example of this in the scene in which Fallopian and Metzger talk (Pynchon 1966: 32):

"You one of those right-wing nut outfits?" inquired the diplomatic Metzger.

Fallopian twinkled. "They accuse us of being paranoids."

“They?” inquired Metzger twinkling also.

“Us?” asked Oedipa.

Because they cannot make a meaning of these words, conversation is futile and therefore it fails. The same happens when Oedipa tries to "impose some order upon the chaotic financial affairs of Inverarity" (Leland 1974: 52). She is unable to do it as the readers of the novel are unable to understand the end of the novel or the meaning of some scenes and such amount of information, because Pynchon did not give a real end to the story. Therefore "We will pit metaphor against metaphor in an endless sorting process form which we will emerge at the other side with information overload; thus, in the final analysis, these attempts to impose pattern are buried in "noise" (Leland 1974: 53). This is similar in some way to White Noise. The characters receive so much information from the media that they are unable to digest it and the effect is the opposite of what it is expected. Therefore, media are a source of information that induce to error and which are able to clarify events and mix them up at the same time. Somehow, Delillo tries to show us that technology in general and television in particular has made us unable of seeing things without thinking of what television has taught us, of thinking for ourselves ignoring what we have previously seen or heard on the media, of judging on our own, because there is a constant noise behind us, in the background of our daily lives that makes it impossible.

Media do not only affect communication for the information said on it but also because of the way in which things are said, that is, because of the specific language employed on television, as well as the specific terms used by people who appear on the news, films and advertisements. Television creates stereotypes and the language used is also reflected in the characters' language. Many of them, in both novels, use generalizations as television as well as a language similar to those of adverts. Hummel refers to this stereotypical language 
in White Noise: "There can be observed a search for colloquial phrases and stereotypes which reduce reality to a familiar domain in which no changes occur. The main repertoire of these phrases stems from television" (2007: 18).

There are many examples of the way in which the side effects of television's constant droning makes advertisements became lodged in the characters' brains. When Jack and Babette go to have dinner at Murray's, they discuss about television and the language of adverts. Murray considers television as the religious medium of America. This is an example of Delillo's critique of television but understanding that the commercialism contains sacred messages. This is clearly exemplified as Babette and Jack return home. They are talking while Jack remembers some names of materials in his head, the first of many times this will happen in the novel: " Dacron, Orlon, Lycra Spandex" (Delillo 1986: 52). There is also a moment in which Jack and Steffie watch television together. She silently mouths the words along with the characters; she would still rather be on television than in the real world: "A little later I watched Steffie in front of the TV. She moved her lips, attempting to match the words as they were spoken" (Delillo 1986:84). Indeed, it is also relevant the fact that Jack uses the word "watched" instead of "saw", a term typically related to television. Steffie is also the protagonist of another scene in which we see the influence of the language employed in television in the characters' own language. Jack observes her sleeping and suddenly she utters "Toyota Celica" (Delillo 1984: 148). This impacts Jack enormously (Delillo 1984: 149):

How could these near-nonsense words, murmured in a child's restless sleep, make me sense a meaning, a presence? She was only repeating some TV voice. Toyota Corolla, Toyota Celica, Toyota Cressida. Supranational names, computer generated, more or less universally pronounceable... Whatever its source, the utterance struck me with the impact of a moment of splendid transcendence.

As Ickstadt (1988:108) says:

Advertisements mediated through posters or an omnipresent television screen, functions as a quasi-religious system of signs which in songs and litanies like "Coke is it, Coke is it, Coke is it" proclaim the true gospel of immanence. It finds its most faithful believers among children, who feel magically safe at home in this world, who greedily absorb all the data and whisper in their sleep magic and incantatory words from the language of advertisements "Toyota Corolla", "Toyota Celica", "Toyota Cressida."

Moreover, television usually reduces scenes and information because of time matters. Some characters like Jack seem to employ the same devices in their daily lives. One example is Jack's lecturing methods that "seem to be deeply influenced by TV's reductive techniques" or the use of typifications, that is, the way in which he identifies objects and people as belonging to a certain type (Hummel 2007:16). He does it when he speaks with Heinrich about the boy's chess friend. He asks the same type of questions that are usually employed on television (Delillo 1986: 44).

There are also examples of the influence that media has on language in The Crying of Lot 49. When Oedipa meets "The Paranoids," Miles sings using an English accent, influenced by television and probably by the most important band appearing on the media 
at that time, "The Beatles." Miles implies in his conversation with Oedipa, that if they want to be successful as the English band, they should sing using English accent and not an American one (Pynchon 1966: 17):

"It's lovely", said Oedipa, "but why do you sing with an English accent when you don't talk that way?"

"It's this group I'm in". Miles explained, "the Paranoids. We're new yet. Our manager says we should sing like that. We watch English movies a lot, for the accent."

The media dictates the ways to become famous and some of the requirements to be popular amongst people, as we see in this example.

Metzger also exemplifies the way in which the media affect the characters' language. As they watch television, there is a moment in which the lawyer is unable to distinguish what is on the film and what is on real life and he speaks and behaves as if he were still participating on the movie (Pynchon 1966: 20): "They lay now, staring at the screen, flanks just lightly touching. There came from the TV set a terrific explosion. "Mines!" cried Metzger, covering his head and rolling away from her."

On the other hand, it is also important in this novel the use of puns and names. Television and commercials use puns that call the attention of the viewer and in some cases incite them to buy their products. Pynchon also makes use of them to show us a way in which language can be used as a means of providing false clues. An instance is the use of language games. One of the most important ones is "KFUCK" that imitates the language of advertisements and can be read in different manners.

It is equally interesting to see how the media do not only affect character's language, but also characters' level of authority in their common lives. Television is able to control reality and also to change authority depending on the attention that protagonists pay to it. Heinrich, in White Noise, is an example of it. During the evacuation, he seems to be the main source of information for the family. He seems to react more reasonably than his father does, because, perhaps as Mcluhan says "the power of the television mosaic to transform American innocence into depth sophistication is most visible in children" (1964:323). Heinrich takes the role of the media during the evacuation, acting as a sort of news caster for his family and once safe in the evacuees' camp he sinks deeper into the role. The evacuees gather around him listening and watching as though he is a television. Because of the confidence that the information provided by television gives him, Heinrich feels free to explain all the symptoms and problems of the airborne toxic event even to unknown people, as a leader, something he would never do with his own family, since he is unable to communicate with them in his everyday life. Jack and Babette also know it and Jack comments "He is probably tired of us. He doesn't think it's worth his while to be funny and charming in front of his family. That's the way sons are. We represent the wrong kind of challenge" (Delillo 1986: 130). In this novel there appears to be no real physical embodiment of a figure of authority, except in certain moments as we saw above, but television and radio, which provide the news, are the only authoritative symbols. For instance, the renaming of the toxic event by television and media gives an idea of control for Jack. Hummel (2007: 31) refers to this: 
The media itself, which tries to control reality through stereotypical representations foster anxiety. The proliferating images of disasters and diseases with their respective symptoms and explanations make the viewer as much anxious as the make him feel secure... The renaming of the cloud can be seen as a sign in gain control over the event...

The Crying of Lot 49 also presents changes in authority, although in this novel authority is not as clear as in White Noise since characters are deeply confused. A clear example is that of Nefastis. He has created a machine that is supposed to violate the Second Law of Thermodynamics, “causing perpetual motion" (Pynchon 1966: 59). This would make him a powerful man who turns into a crazy scientist unable to control his own impulses. Indeed, Marxwell's Demon is only effective if an individual is sensitive enough to communicate with it. Paradoxically, he is unable to communicate to anybody and to prevent his own interest on television. In fact, his only hope is that Oedipa will have sex with him in front of television. His possible authority is vanished as he behaves in such a way.

Finally, it is also important to notice the relationship between drugs and media, and how this relationship affects communication. Both in White Noise and The Crying of Lot 49 we find examples of drugs and failure of communication. In Delillo's work Dylar becomes related to television in a clear way through the figure of Mink. Dylar is supposed to avoid fear to die but what Jack finds when he is looking for Babette's lover is a man in a motel room who continuously takes Dylar pills and watches television. Channels are changed and Mink repeats some random commercials and even his physical appearance reminded of a television set: "His face was odd, concave, forehead and chin jutting. He was watching TV without the sound" (Delillo 1986: 292). Because of the effects of Dylar and television, which as in many other scenes in the book behaves as a background noise, their conversation does not lead them anywhere. The same happens when Oedipa tries to speak with her husband. Mucho has started taking LSD and when Oedipa realizes about it, she also knows that it is too late to try to maintain a conversation with him. She has lost him: "Now he would never be spooked again, not as long as he had the pills. She could not quite get into her head that the day she'd left him for San Narciso was the day she'd seen Mucho for the last time. So much of him already had dissipated" (Pynchon 1966: 100).

The close relationship existing between communication and media is clearly exemplified, therefore if we pay attention to all the aspects mentioned above. Media becomes one of the most important parts in American culture, especially television. It is the background noise in most American houses and as reflected in many scenes in The Crying of Lot 49 and White Noise. It interrupts important and common conversations and makes protagonists pay more attention to it than to their own events, preventing themselves from communicating appropriately and interfering in important moments.

In general, media becomes the most important source of information, getting to such an extent that those events that do not appear on television are not real or worth to be remembered, altering the characters' behavior and affecting the way of addressing and trusting other's opinions. Indeed, as shown above, television prevents characters' ability to think on their own but it also puts characters in situations which are out of their common life, making them feel independent and indifferent from what it is shown on it. This is opposed when they have to 
confront situations in which reality and television are mixed up, as the airborne toxic event, or the moment in which some protagonists appear on the media. It is also important to notice that although media usually transmits information, this information is not always good or valuable. There are many examples of misinformation due to the influence of television in both works and this leads to many failures in communication. That is, the idea that communicating is transmitting information is not always present in the novels and this work tries to exemplify it with the analysis of many scenes. Indeed, the concept of noise, so important in White Noise, is also present in The Crying of Lot 49. Equally important is the influence that media has on the characters' language. Television and radio create stereotypes and make use of specific language, like that appearing on adverts and which is also employed by characters in many moments. As explained here, media also affects authority, and consequently the characters' way of communicating in front of other people. Finally, drugs, communication and media are also closely connected as it has been examined.

\section{REFERENCES}

BAUdRILlard, J. 1998. Simulacra and Simulations. Stanford: Stanford.

CoYle, M. ET AL. 1991. Encyclopedia of Literature and Criticism. New York: Gale Research Inc.

Delillo, D. 1986. White Noise. New York: Penguin Books.

Geddes, D. 2002. “Distorted Communication in Pynchon's The Crying of Lot 49. ”The Satirist. 3 Sept 2017. http:/www.thesatirist.com/books/TheCryingOfLot49.html.

Hummel, V. 2007. “Television and Literature: David Foster Wallace's Concept of Image Fiction, Don Delillo's White Noise and Thomas Pynchon's Vineland." The Guardian. 21 Jun, 2008. http://home.foni.net/\%7evhummel/Image-Fiction/Toc.html.

ICKSTADT, H. 1988. “Contemporary American Novel: Between Post- Modernism and Neo- Realism". Actas del XII Congreso Nacional de AEDEN. Alicante: Universidad de Alicante. 99-109.

Leland, J. P. 1974. "Pynchon's Linguistic Demon: The Crying of Lot 49.” Critique 45-51.

McLuHan, M. 1964. Understanding Media: The Extensions of Man. New York and London.

Miller, M. C. 1988. Boxed in: The Culture of TV. Evanston, IL: Northwestern UP.

Pynchon, T. 1966. The Crying of Lot 49. London: Vintage.

TichI, C. 1989. “Television and Recent American Fiction.” American Literary History. 110-130. 